\title{
AD HOC CONSULTANT IN THE ASSESSMENT OF SCIENTIFIC PUBLICATIONS
}

Scientific journals, with the passage of time and the expansion of the demands of the publishing market, have extended the responsibility to offer readers original articles that contain innovations, clear proposals, theoretical contributions and practical effective results that can be recognized for their quality in the national and international context. Thus, the commitment of the chief editor, the associate editors, the editorial board and the ad hoc consultants, becomes more complex in order to strength the progress of science, the scientific validity of publications and the visibility of the productions of researchers.

To meet the arduous task of holding that production, journals should be able to respond at the continuously growing demand and, for this; they adopt different evaluation processes that lead to approval or reject the received manuscripts. Within these processes, we will focus our attention on this text, in the role and importance of the work done by the ad hoc consultants. The peer review process, also known as arbitration system or referee system, is considered an essential element in the process of knowledge production and development science.

The Text \& Context Nursing Journal (T\&C) in order to maintain the quality of its publications, has a select body of ad hoc consultants, formed by researchers with vast and recognized experience in certain areas of knowledge, having the function of evaluating the rigor and scientific merit of the submitted work to this journal. For this, editors have been improving, over time, the criteria for the registration of ad hoc consultants; generally, they are professionals with doctoral level of academic training in the area of health and nursing, humanities and social sciences. These professionals are invited to contribute to our journal and to indicate their areas of expertise, being able from that time, to be part of the group of ad hoc consultants of the T\&C as evaluators. The T\&C recognizes currently in its system around 760 ad hoc national and international consultants.

The chief editor as well as the associate editors when receiving a manuscript perform a process of pre-analysis. This is the initial assessment that includes: a review of the adequacy of the norms of the journal, to verify if the topic of the work is interesting in accordance with the field of the journal and also if it takes into consideration the general scope of the journal, but mainly, they check for the contribution that the manuscript could provide to the advancement of knowledge related to the area of health and especially to nursing. When a manuscript is approved at this stage, it is sent to the ad hoc consultants to proceed with the critical reading and the elaboration of the technical report. These consultants, who conducted the analysis anonymously, are fundamental in the process of selecting the best manuscripts, as well as the indication of the necessary adjustments to the acceptance of the manuscript.

The Text \& Context Nursing Journal, in 2015 (until September), approved 290 manuscripts at the stage of pre-analysis and subsequently sent them to the evaluation of de ad hoc consultants. Considering the hypothesis of the performance of two consultants per manuscript, then we would have the participation of nearly 580 consultants in this period. Thinking of the possibility that about $20 \%$ of these consultants cannot perform this evaluation, we then have to find another consultant, corresponding to 116 new consultants. In the event that the manuscript receive conflicting or inconsistent views, the submission editors also need to select an additional consultant for this evaluation.

Those numbers show that with the increase of the production in the area, the availability of consultants that send the evaluations should be also extended, once that these evaluations are a sine qua non condition for publication. This reality faced by the T\&C Nursing Journal, clearly is not different from other journals in Nursing or other areas of knowledge. This numerical factor has generated difficulties and overload the ad hoc consultants; who receive a high and increasingly volume of solicitations that could compromise the compliance with the deadlines and the accuracy of the evaluation. This situation directly influences the time that the journal has between the submission of the manuscript and its publication, which is also a quality criterion to be evaluated by International Journal of Indexing and for to the SciELO database itself. For the researcher, the time while editors and leading consultants take for the evaluation and publication, interferes with the visibility of the produced knowledge and his/her career itself.

We understand that the commitment and responsibility of the ad hoc consultant for the issuance of the evaluation, it is essential to ensure the quality of the published articles by journals; therefore, they play a key role in the knowledge that has being transferred. For this, the consultants must have theoretical and methodological expertise over the approach subject in order to build a constructive and well-crafted report. Considering all these aspects, for each manuscript, the editors made a careful selection of the registered consultants, having the best condition to contribute effectively with this evaluation.

Another situation that integrates the process of ad hoc consulting is the gratuitousness of the reviewing process by the consultant. In the Brazilian reality, for example, the consultants do this work voluntarily, without any gratification, whether financial, or exemption of fees of the journals, or any other benefit. This, in a way, becomes less attractive to the consultant to do this work. However, we believe that this activity is a contribution to the development of the discipline and helps in the revision of their own manuscripts, generating a reciprocal action between publishing and participating in the selection process of the publications. Furthermore, as we have accompanied over time, there is an important academic recognition point that makes people to look for this work, however this has not been enough to guarantee an excellent revision. ${ }^{2-3}$

In order to engage reviewers in the evaluation of the ad hoc evaluation process, several national and international journals are adopting the open system or open review, in which both parties know the identity of the authors and reviewers. ${ }^{4-5}$ This identification may contribute to the commitment to elaborate an educational, collaborative, constructive, consistent and non-punitive evaluation, considering the peer recognition in this assessment process. However, the T\&C continues adopting the closed system or blind review because, despite the difficulties demonstrated above, we still believe in the importance of confidentiality throughout the assessment process.

It is noted the opportunity that authors and consultants have in this reviewing cycle, related to the learning process; as analyzes allow to the development of critical thinking, acting on training and perfecting them. Besides, the essential work of consultants emitting detailed reports and that from an ethical perspective could give a significant contribution to the authors to the extent that their criticisms and suggestions promote the qualification and development of the research they conducted and help evaluate the science, contributing to its development and the maintenance of quality standards of journals. ${ }^{6}$ 
We hope that this editorial can contribute to the essential and urgent reflection on the important and indispensable role of $a d$ hoc consultants to meet the fast growth of science and the production of knowledge in nursing and health and to ensure the maintenance of quality among the scientific publications.

\section{REFERENCES}

1. Triggle CR, Triggle DJ. What is the future of peer review? Why is there fraud in science? Is plagiarism out of control? Why do scientist do bad things? Is it all a case of: "all the is necesary for the triumph of evil is that good men do nothing?" Vasc Health Risk Manag. 2007; 3(1):39-53.

2. Jenal S, Vituri DW, Ezaías GM, Silva LA, Caliri MHL. O processo de revisão por pares: uma revisão integrativa de literatura. Acta Paul Enferm [online]. 2012 [cited 2015 Oct 22]; 25(5):802-8. Available from: http://www.scielo.br/scielo.php?script=sci_ arttext\&pid=S0103-21002012000500024\&lng=en

3. Botomé SP. Avaliação entre "pares" na ciência e na academia: aspectos clandestinos de um julgamento nem sempre científico, acadêmico ou "de avaliação". Psicologia USP [online]. 2011 [cited 2015 Out 22]; 22(2):335-56. Available from http:// www.scielo. br/scielo.php?script=sci_arttext\&pid=S0103-65642011000200003\&lng=en\&tlng=pt

4. Nayak BK, Maniar R, Moreker S. The agony and the ecstasy of the peer-review process. Indian J Ophthalmol [online]. 2005 [cited 2015 Oct 26]; 53(3):153-5. Available from http:/ / www.ijo.in/article.asp?issn=0301-4738;year=2005; volume=53;issue=3; spage=15 3;epage $=155$;aulast $=$ Nayak

5. Rochon PA, Bero LA, Bay AM, Gold JL, Dergal JM, Binns MA, et al. Comparison of review articles published in peer-reviewed and throwaway journals. JAMA [online]. 2002 [cited 2015 Oct 26]; 287(21):2853-6. Available from: http://jama.jamanetwork.com/ article.asp ? volume $=287 \&$ page $=2853$

6. Reiners AAO, Costa ALRC, Zborowski IP, Lourenço MR, Hortense P, Sant'Anna RPM. Evaluation in science and technology: the peers' role in reviewing papers for publication in journals. In: Proceedings of the 8 . Brazilian Nursing Communication Symposium [online]; 2002 May 02-03; São Paulo, SP, Brazil. 2002 [cited 2015 Oct 26]. Available from: http:/ / www.proceedings.scielo.br/scielo. php?script=sci_arttext\&pid=MSC0000000052002000100002\&lng=en\&nrm=van

Maria Itayra Padilha

Ph.D. in Nursing. Titular Professor of the Nursing Department and the Postgraduate Nursing Program at the Federal University of Santa Catarina (PEN/UFSC). Editor-in-Chief of the Text \& Context Nursing Journal.

Odaléa Maria Brüggemann

Ph.D. in Obstetrics and Gynecology. Submission editor of the Text $\mathcal{E}$ Context Nursing Journal. Professor of the Nursing Department and of the PEN/UFSC. CNPq Researcher.

\section{Roberta Costa}

Ph.D. in Nursing. Professor of the Nursing Department and of the Professional Master's Degree in Health Care Management at the UFSC. Submission editor of the Text $\mathcal{E}$ Context Nursing Journal.

Luciana M. da Rosa

Ph.D. in Nursing. Professor of the Nursing Department. Submission editor of the Text $\mathcal{E}$ Context Nursing Journal.

Denise Maria Guerreiro Vieira da Silva

Ph.D. in Nursing. Titular Professor of the Nursing Department and of the PEN/UFSC. Selection Manuscripts editor of the Text $\mathcal{E}$ Context Nursing Journal.

Mara Ambrosina Vargas

Ph.D. in Nursing. Professor of the Nursing Department and of the PEN/UFSC. Selection Manuscripts editor of the Text E Context Nursing Journal.

Maria Elena Echevarría-Guanilo

Ph.D. in Nursing. Professor of the Nursing Department at the UFSC. Selection Manuscripts editor of the Text \& Context Nursing Journal.

Francis Solange Vieira Tourinho

Ph.D. in Child and Adolescent Health. Professor of the Nursing Department at the UFSC. Text and Layout Editor of the Text $\mathcal{E}$ Context Nursing Journal

Selma Regina de Andrade

Ph.D. in Nursing. Professor of the Nursing Department and of the PEN/UFSC. Text and Layout Editor of the Text E Context Nursing Journal 